\title{
Glenn Hernandez
}

\section{Everything started on a rainy day in Santiago}

Received: 12 January 2013

Accepted: 17 January 2013

Published online: 22 February 2013

(C) Springer-Verlag Berlin Heidelberg and ESICM 2013

G. Hernandez ( $\bullet)$

Pontificia Universidad Catolica de Chile, Santiago, Chile e-mail: glennguru@gmail.com

\author{
"I am nothing. \\ I shall always be nothing. \\ I cannot wish to be anything. \\ Aside from that, I have within me all the dreams of the world"
}

Fernando Pessoa

What makes a maestro? I have asked this question myself many times during my long career as an academic intensivist. I do not have the answer, but I do know that, at least for me, it's much more than simply being a good teacher or clinician or researcher. It probably has to do with the ability or virtue to induce in others some sort of enlightenment or internal commotion that eventually leads to major changes at vocational, spiritual, lifestyle, or commitment levels. It's a shooting star illuminating the misty forest or the ridge of a snowy mountain after we lose our way in the middle of a storm. It's a lighthouse at the edge of the world radiating dreams, passion, or perseverance. As the Chilean poet Marcelo Rioseco wrote, "There is no greater beauty than an intense life," and we always need someone to remind us of this essential fact.

Many years ago as a young internal medicine resident, I met a real maestro for the first time. Professor Max Harry Weil (1927-2011) was lecturing in Chile and I attended the meeting, driven by a personal interest in the subject of shock. I was a little late for his first lecture, related to "end of life care." As I entered the dark auditorium, a picture of a crumpled piece of paper with some barely legible handwritten words was displayed on the screen as his voice rose from the podium. I may not recall all of the words exactly, but the heart of his speech was as follows:

I was a young resident desperately fighting against a massive hemoptysis in a dying teenager with an old bronchoscope. Minutes passed, anguish increased, until the boy took this paper in a brief instant of stability and wrote with trembling hands, "Let it go, nothing to do." We were all paralyzed and moved, and stopped resuscitation minutes thereafter. Much later I understood that it was a matter of respect, of compassion, of dignity.

After the conference I walked outside. It was a rainy day that I remember well. Santiago is surrounded by the snowy Andes to the east and the south. Another mountain range separates the city from the cold Pacific Ocean to the west. Absorbed by this impressive landscape, it took me some minutes to realize that I had experienced a crucial life event, a sort of epiphany. I had encountered the fascinating alchemy between physiology and humanism for the first time, a subject that has been my driving force as a Professor of Intensive Care Medicine for almost two decades. That was it, a maestro on a rainy day in Santiago, and the irreversible decision to become an intensivist.

Over the years I learned more and more about Dr. Weil's enormous contributions as a researcher and a master teacher. I read with devotion countless papers that he had authored. I smiled at a figure of a great toe temperature sensor. I become elated by his pathophysiological speculations. More importantly, I learned through different testimonies about his enthusiasm, his kindness, his generosity, his modesty, and his passion. A maestro is by definition a passionate dreamer in Hölderlin's sense of human life: "Man is a god when he dreams."

When I look back on my life as an intensivist I also remember moments of bewilderment, confusion, anguish, 
sadness, or doubt appearing in the dust of this long and winding road. Moments where I felt what the great Ezra Pound sang of in his late cantos: "I lost my center fighting the world. The dreams clash and are shattered. Let the wind speak, that is paradise. Let the gods forgive what I have made." It is precisely in these occasions when we need maestros, but where can we find them? Eventually, in heterogeneous and unorthodox places such as old physiology textbooks, long forgotten papers, obituaries, a statue on the campus, or a silent portrait on the library wall. I can imagine many ancient physiologists fighting against adversity and skepticism, but it was the master of masters, Arthur C. Guyton (1919-2003), who gave us a monumental lesson of endurance and resilience. At the age of 27 and close to being graduated as a brilliant cardiovascular surgeon at Harvard, he was attacked and crippled by polio. As a consequence, he had to abandon his surgical career and drastically reinvent himself. It was then that he decided to concentrate the rest of his academic life in physiology research and teaching, a fundamental decision for the history of modern and cardiovascular physiology. But what is exceptional is that he faced this new task with renewed enthusiasm and passion, without losing his dreams or even his imperturbable, benevolent smile. As Antoine de Saint-Exupéry wrote, "What makes the desert beautiful is that somewhere it hides a well," and this is what a maestro is all about.

When he died, Professor Roger C. Bone (1941-1997), the most paradigmatic representative of the holistic symbiosis between science and humanism in critical care, left a collection of immortal words and reflections about the process of death. I can imagine him, a courageous human being and incomparable master, enjoying three different sunsets each day over the roaring Maumee River with his beloved wife, surrounded by herons, woodpeckers, poets, and classical musicians [1]. When I think about this, I am immensely proud of being an intensivist. And everything started on a rainy day in Santiago, many, many years ago when I met a real maestro for the first time.

Conflicts of interest I declare that I have no conflict of interest.

\section{Reference}

1. Bone RC (1996) A piece of my mind. Maumee: my Walden Pond. JAMA 276(24):1931 